\title{
RESEARCH OF THE APPLICATION OF GAMES IN TEACHING JUDO TO CHILDREN FROM 7 TO 10 YEARS OF AGE
}

\author{
V. Lukanova* \\ Department of Sport, Sofia University “St. Kliment Ohridski”, Sofia, Bulgaria
}

\begin{abstract}
Objective: Conduct and follow-up experiment with the aim of improving and refining the methods of initial training in judo for children 7-10 years of age with the help of specialized judo games. Modern methods of training in many sports, particularly in judo, are characterized by early specialization. In this respect, some existing training programs may be immaturity when the age characteristics of beginners are not taken into account and, as a result, children's health suffers from adverse consequences. Primary Judo training methods open up a vast space for improvement and development of this type of sport. The author initiates and practices process of teaching and learning in basic training beginners judo, using judo games as a means to fully develop the physical characteristics and layout of racing skills.
\end{abstract}

Key words: judo, training, research, methodology, games, modernization.

The working hypothesis of this work is to demonstrate that incorporating a range of games that are structurally close to the technical actions and structure of judo sport and studying them according to the curriculum of the Judo Initial Teaching Groups would enhance the results and increased the effectiveness of what has been learned. These results would be due not to added time but to new methods. The study analyzes the initial training of young Judoists. Judo is a highly coordinated, situational, contact-based sport and has a significant impact on the body of all practitioners during training and racing. The results and impact of developed and specially selected games with a specialized focus on the training of judo contestants in the initial stage of learning are the focus of the research in this article.

The brief analysis of the scientific literature shows the prevalent and established belief that improving sports training depends to a large extent on the correct physical selection of

\footnotetext{
*Correspondence to: Assistant: Valeria Ivanova

Lukanova, Department of Sport, Sofia University "St. Kliment Ohridski", 1504 Sofia, Bulgaria, Email:valeria.lukanova@gmail.com,Phone: $+359898446639$
}

athletes starting with a very early stage of practicing combat. It has been found that the most appropriate approach to addressing this problem is the need to select physical drilling tools and techniques, taking into account the specifics of the racing exercises that underlie the complex impact method. (1)

The 7-10 years age-based approach is of paramount importance as it lowers the level of stress and anxiety in children and improves their concentration with clearly set goals and tasks. The problem of the relationship between skills and concepts in the learning process is an important moment in the development of operational qualities in the personality. Judo is a Japanese martial art, and the techniques, commands and rituals are Japanese. In Bulgaria, there is some underestimation of training to build knowledge-based skills as a specific methodology that complicates the operational work between professionals and athletes. It is therefore even more imperative to teach skills and knowledge in optimal terms. This is especially true for children where this relationship will be more lasting and more impressive for themselves. (2)

In the existing literature on scientific methods, there are many cases where special exercises 


\section{LUKANOVA $V$.}

do not meet the target indicators and do not provide for the development of the physical characteristics of children that are needed in sporting uniforms. Therefore, the pedagogical experiment has developed and tested the methods of interrelated development of physical features and the shaping of actionoriented combat skills in novice children, deliberately using specialized judo games. In the course of the pedagogical experiment, the hypothesis of a more efficient (compared to traditional methods of training) development of the physical characteristics and motor skills of the children in the initial training groups has been proved. It has been shown that developed methods of using gaming technology actually better influence the development of strength and speed in children's judges.

As can be seen, the effective influence of specialized judo games on the development of these physical qualities in trainees is characterized by the fact that many movements in these exercises are based on overcoming opponent's resistance and, to a greater extent, require learners to demonstrate the qualities of strength and speed. Studies (3-6) and others testify to action-ori-ented games as one of the effective means of influencing the power and speed training of novice athletes.

The results obtained confirm the information in the literature $(7,8)$ and others. On the possibility of an effective solution to the issue of training the basics of the battle through play. The analysis and summarization of the literature by scientific methods in view of the actual state of the studied subject proves the topicality of the topic. The research of works written by physiologists, psychologists and pedagogues enables us to assess the possibilities and understand the age specifics of the chosen age range of children - and to build a process for the initial stage of learning based on the data obtained.

Pedagogical observation, pedagogical experiment, and mathematical statistics methods were used to complete the study. To accomplish the selected tasks, two groups of children were selected: experimental (14 boys) and control (14 boys), all 7-8 years old. The control group is trained in a traditional program, the experimental group is trained on the developed methods, focused on carefully selected gaming material.

At the beginning of the experiment, physical fitness was assessed by fitness tests that assessed strength, dexterity, speed, endurance. These tests aim to determine the initial physical fitness level of children at the start of the experiment and, therefore, the formation of homogeneous groups with an approximately similar level of fitness to ensure the validity of the experiment. After detecting the results of the experiment participants, they were divided into two control and experimental groups. The control group selected beginners with higher test results, and in the experimental those with lower ones. Analyzing the results obtained led to the finding that the gaming model and judo initial training for 7-10 year olds gives higher scores and changes.

The experiment took place within two academic sessions. After taking the data of participants at the beginning, middle and end of the experimental period. The task was to track the changes in the level of physical development influenced by commonly practiced learning methods and methods using judo games and their comparison.

In the control group, the growth of indicators before and after the pedagogical experiment changed gradually and gradually (Table 1). In the experimental group, progress was clearly pronounced. There is a leveling with the result of the control group and overtaking them in almost all test disciplines.

Extremely important changes have been observed after the experiment between the experimental and control groups during the shuttle run $4 \times 9 \mathrm{~m}$, $30 \mathrm{~m}$ running, long jumps, high jumps, 5-minute jogging, dynamic equilibrium when performing a turn on a gymnastic bench, running to numbered balls (Table 1).

Changes in the above-mentioned data are a result of the long-term application of carefully selected games and exercises aimed at the development of agility, strength and speed, which in this age group are developing at the fastest pace.

The development of these capabilities in the control group was essential. Approximately $70 \%$ of the time spent on general strength training. In the experimental group the time allowed for the development of quality force was $30 \%$. With confidence we can say that the results in the test group increased due to the methods of the game and some special exercises. This shows that despite the less time spent in exercises to develop strength in the experimental group, thanks to innovative methods and without additional physical overload, the children managed to demonstrate almost the same results in their development. 
LUKANOVA $V$.

Table 1. Comparative characteristics of the overall physical fitness of children in the experimental group and the control group at the end of the experiment

\begin{tabular}{|c|c|c|c|c|c|c|c|c|c|}
\hline \multirow[t]{2}{*}{ № } & \multirow[t]{2}{*}{ Type of exercise } & \multicolumn{2}{|c|}{ Starter } & \multicolumn{2}{|c|}{ Intermedial } & \multicolumn{2}{|c|}{ Final } & \multicolumn{2}{|c|}{ Variation } \\
\hline & & $\begin{array}{l}\text { control } \\
\text { group }\end{array}$ & $\begin{array}{l}\text { experi } \\
\text { mental } \\
\text { group }\end{array}$ & $\begin{array}{l}\text { control } \\
\text { group }\end{array}$ & $\begin{array}{l}\text { experi } \\
\text { mental } \\
\text { group }\end{array}$ & $\begin{array}{l}\text { control } \\
\text { group }\end{array}$ & $\begin{array}{l}\text { experim } \\
\text { ental } \\
\text { group }\end{array}$ & $\begin{array}{l}\text { control } \\
\text { group }\end{array}$ & $\begin{array}{l}\text { experim } \\
\text { ental } \\
\text { group }\end{array}$ \\
\hline 1 & Running $30 \mathrm{~m} / \mathrm{s}$. & 5,8 & 6,1 & 5,75 & 5,95 & 5,59 & 5,43 & $-0,21$ & $-0,43$ \\
\hline 2 & Shuttle Run 4x9m / sec. & 9,8 & 10.5 & 9,7 & 10,18 & 9,38 & 9,27 & $-0,42$ & $-1,27$ \\
\hline 3 & Long jump / cm & 194 & 189 & 195 & 191 & 197 & 195 & +3 & +6 \\
\hline 4 & $\begin{array}{l}\text { High jump from place / } \\
\mathrm{cm}\end{array}$ & 43 & 41 & 44 & 43 & 46 & 46 & +3 & +5 \\
\hline 5 & Running $5 \mathrm{~min} / \mathrm{m}$ & 1020 & 970 & 1120 & 1080 & 1190 & 1180 & +170 & +210 \\
\hline 7 & Pull ups/1min & 10 & 11 & 11 & 12 & 12 & 14 & +2 & +3 \\
\hline 8 & $\begin{array}{l}\text { Abdominal presses } / 1 \\
\text { min. }\end{array}$ & 42 & 41 & 43 & 42 & 45 & 46 & +3 & +3 \\
\hline 9 & $\begin{array}{l}\text { Dynamic equilibrium in } \\
\text { execution } \\
\text { gymnastic turns on the } \\
\text { bench }(\mathrm{sec} .)\end{array}$ & 12 & 10,4 & 12,07 & 10,53 & 12.28 & 10,97 & $+0,29$ & $+0,57$ \\
\hline 10 & $\begin{array}{l}\text { Run to numbered medical } \\
\text { balls (sec.) }\end{array}$ & 10,4 & 11 & 10.32 & 10,86 & 10,07 & 10,39 & $-0,33$ & $-0,61$ \\
\hline
\end{tabular}

This pedagogical experiment has shown that profiled games aimed at speed and coordination are effective tools of developing dexterity in young Judo. Obviously, this can be explained by the fact that in game activity tasks are performed each time in new unpredictable and suddenly changing conditions under active resistance of the competitor. The competitors must react quickly and correctly to the actions of their opponents, showing creativity, vitality, and so on.

A very large impact of the selected games on the development of agility is demonstrated in the changes of the dynamic balance and the spatial orientation.

The results obtained show reciprocity and similarity to the results shown in the works for the successful application of games in the development of the game of skill (9).

It has been established that the established methodology for the implementation of educational Judo games has a positive impact on the development of the general physical qualities. In the game, because of its inherent emotionality, students can show remarkable effort and resistance, leading to a corresponding progress in the development of endurance. We can assume that the more efficient development of the athletes by using the technique of the game is explained by the fact that during the game, the students' opposition to the pedagogical influence is inactive, which gradually leads to a conscious co-operation in the achievement of higher results.

As noted, the methodology for using specialized judo games during the training of primary education groups is applied not only to the purposeful development of physical capabilities, but at the same time it influences the shaping of competitive skills and therefore more effective mastery of Judo techniques.

The results of the pedagogical experiment confirm that the participants in the experimental group have mastered the technique faster and better. After analyzing the dynamics of the kata technique and their use in judo competitions using traditional methods and then comparing them, we can assert that the developed methods of using judo games are more effective in shaping stable and longlasting technical skills and physical qualities in the initial training of practicing judo children aged 7-10 years. As a result of the experiment, we have confirmed the assumption that specialized judo games have a widespread impact on the development of physical qualities and the effectiveness of learning techniques in the initial stage of learning. 
LUKANOVA $V$.

In conclusion, we can add the following observations and findings:

1. The analysis of literary sources on sporting uniformity makes it possible to establish that the issue of justifying methods using specialized action-oriented games aimed at the development of physical qualities and martial arts skills in young Judo at the stage of initial sports training is insufficient developed. In the literature, there are no recommendations for the rational selection and introduction of judo games in the structure of learning practice, nor for their relationship to other learning methods for that age.The material of the game in the literature is insufficiently generalized or systematized in terms of judo. There is no evidence of its effectiveness in carrying out initial Judo training courses.

2. The main drawback of traditional technology is the heavy management of the learning process. This does not allow the individualization of technical skills and the extraction of mobility skills in a sufficient volume. Study and interviews with lecturers and coaches allow the role of the current program to be identified as a mandatory document, which recommends that professionals rely on the choice of a strategy for the training of children in judo.Taking into account that such a document can not influence the shaping of the methodological views of trainers, it is important to note the following:

-trainers and teachers are positive about using the game's method in teaching kids to play Judo. Unfortunately, most of the methodological literature on the topic is either poorly adapted or needs further modifications. The educational program lacks a list of proposed game modes and their classification. And in methodical literature, which is rare, their classification is not convenient for practical use;

Opractically many teachers do not follow the recommendations and the official program; the content of the curriculum and its sequence are formed and executed according to their professionalism, readiness and experience;

-In existing training methodologies, there is an essential opening for the introduction of action-oriented, action-oriented games without taking time from general training. Moreover, the introduction of gaming methods positively affects the emotional state of young athletes. This helps to stabilize the contingency and effectiveness of learning technical and tactical actions.
3. It has been established that the total time spent on a training lesson to improve the physical qualities of beginner athletes and the learning of technical and tactical activities by means of specialized games of movement must be (depending on the current tasks) of 24 up to 45 minutes. The organizational and methodological features of game-based lessons allow the use of specialized games such as short time tasks (30-60 seconds), high (sometimes maximum) tasks, with a repeating maximum of 3-5 times - in order to increase the speed of learners ; long-term tasks (from 3 to 10 minutes) aimed at increasing consistency. 4. It is noted that the most important pedagogical features of gaming complexes in the initial training of judo players are: creating a lasting interest in judo, enhancing physical readiness and formulating racing skills.

5. It has been shown that specialized judo games as a set of games - tasks with multidimensional influence - very effectively influence the development of the motor skills of the children in the experimental group. Particularly clear is seen in a comparative analysis of the parameters in (Table 1).

6. As a result of the experiment, the participants of the experimental group achieved higher results in the kata training technique, although in this group the determined learning time was less than the control group. The positive influence of specialized action-oriented judo games on the quality and speed of learners is clearly demonstrated in the results. This proves that learning technology using games is more effective than traditional form of learning.

7. On the basis of the analysis of the competitions between the control and experimental groups it can be said that the individualization and the variability of the experimental group's techniques and tactics contribute significantly to the structure of their readiness. A statistically proven distinction is observed in relation to all parameters of technical and tactical readiness: active struggle, variability, efficiency and ability to achieve good results.

8. The most rational thing is the consistent study of the tasks of the game. Further gaming tasks gradually become more sophisticated, using techniques according to the program for a particular degree. Later training tasks are advanced by introducing games that include elements of a tackle by choosing the most rational way to solve a given task. It may be beneficial for teachers of physical education at primary and secondary schools to develop 
over-activity and to formulate a broad base of movement, psychological preparation for future workloads in the process of refinement and formulation of technical facilities, elaboration of individual learning tasks, further professional development of students, practitioners or not, judo.

\section{ACKNOWLEDGMENTS}

This article is published with the financial support of Project No 80-10-62 / 10.04.2019, according to Order No. 9 of the State Budget of the Republic of Bulgaria.

\section{REFERENCES}

1. Димитрова Н., Насиев Ер., Павлов Хр.; „Количествена оценка на физическата годност в начална училищна възраст“, Научна конференция „Предизвикателства и перспективи пред спортната наука“, „Специфика на подготовката в различни спортни дисциплини“- 2017г. ; HCA ПРЕС; стр.197-204; София, 2017 ISBN 978-954-718-492-3

2. Янева А., Изследване на степента на усвояване на двигателните умения и връзката им с понятията при обучението по джудо в детската градина. Годишник
LUKANOVA $V$.

на СУ"Св. Климент Охридски", Департамент по спорт, том 85, 2009;

3. Geller Ye.M., Rudnitskiy V.I., Raspopov S.N. Social pedagogical functions of games in a training of young wrestlers. Abstract from VI Scientific conference. Tallinn.1980;

4. Konovalova I.A. Effectiveness of the game method in training of groups of young swimmers. M. 1990;

5. Krepchuk I.I. Complemented impact of action-oriented games on physical qualities and combat skills of young wrestlers at the initial stage of training. Minsk. 1987;

6. Stankiavichus L.A. Effectiveness of actionoriented games in cultivating of movement qualities of primary schoolchildren at physical culture lessons. Author's abstract. Kyiv. 1983;

7. Jagello W. Wydolnosc fizyczna ogolna mlodych judokow na tle rozwoju somatycznego. Roczniki Naukowe AWF Warszawa 2000, t. XXXIX;

8. Rybalko V.M., Krepchuk I.I., Geller Ye.M. Classification of specialized game methods in sports wrestling. 1986;

9. Vilenskiy Yu.M., Dubovis M.S. Games in sports wrestling. Kyiv, Zdorov'ya. 1977; 